\title{
Lessons Learnt from Full-Scale-Tests of Bridges in Croatia and Sweden
}

\begin{tabular}{|r|l|}
\hline Journal: & IABSE Symposium Nantes 2018 \\
\hline Manuscript ID & Nantes-0479-2018.R2 \\
\hline Theme: & $\begin{array}{l}\text { NEW TRENDS FOR INNOVATIONS IN THE CONSTRUCTION, THE } \\
\text { PRESERVATION, THE EXPLOITATION AND THE UPGRADING OF } \\
\text { STRUCTURES }\end{array}$ \\
\hline Date Submitted by the Author: & n/a \\
\hline Complete List of Authors: & $\begin{array}{l}\text { Duvnjak, Ivan; Sveuciliste u Zagrebu Gradevinski Fakultet, ; } \\
\text { Bartolac, Marko; Sveuciliste u Zagrebu Gradevinski Fakultet } \\
\text { Nilimaa, Jonny; Luleå university of Technology, Dept of Civil, } \\
\text { Environmental and Natural Resources Eng. } \\
\text { Sas, Gabriel; Luleå university of Technology, Dept of Civil, Environmental } \\
\text { and Natural Resources Eng. } \\
\text { Blanksvärd, Thomas; Luleă university of Technology, Dept of Civil, } \\
\text { Environmental and Natural Resources Eng. } \\
\text { Täjsten, Björn; Luleå university of Technology, Dept of Civil, Environmental } \\
\text { and Natural Resources Eng. } \\
\text { Elfgren, Lennart; Luleå University of Technology, Department of Civil, } \\
\text { Environmental and Natural Resources Engineering }\end{array}$ \\
\hline \multirow{2}{*}{ Keywords: } & $\begin{array}{l}\text { Concrete < Material and Equipment , Steel < Material and Equipment, } \\
\text { Prestressing < Material and Equipment }\end{array}$ \\
\hline
\end{tabular}




\title{
Lessons learnt from Full-Scale Tests of Bridges in Croatia and Sweden
}

\author{
Ivan Duvnjak, Marko Bartolac \\ University of Zagreb, Zagreb, Croatia \\ Jonny Nilimaa, Gabriel Sas, Thomas Blanksvärd, Björn Täljsten and Lennart Elfgren \\ Luleå University of Technology, Luleå, Sweden \\ Contact: lennart.elfgren@ltu.se
}

\begin{abstract}
Load testing is a way to control the capacity and function of a bridge. Methods and recommendations for load testing are described and examples are given form tests carried out in Croatia and Sweden. In order not to damage the bridge being tested, the load must be limited, often to be within the serviceability limit state (SLS). Numerical models can be calibrated by load tests and then be used to check the carrying capacity for higher loads than what has been tested. Need for further work and recommendations are discussed. By effective planning, costs can be saved and a more sustainable use of bridges can be obtained.

Keywords: Load testing, proof loading, collapse, deformations, serviceability limit state (SLS), numerical modelling, stiffness
\end{abstract}

\section{Introduction}

Load testing is one of the oldest ways to check the quality of a bridge [1]. The deformations of a bridge during loading summarize its general condition and stiffness. Thus, the deformation is identified as a key performance indicator in the COST Action TU1406 "Quality specifications for roadway bridges, standardization at a European level", [2], [3]. In this paper some examples and experiences are given from load testing in Croatia and Sweden; how quality control and management of bridges can be improved and how numerical models may be calibrated.

Load testing can be performed at (a) service-load levels and (b) loads to check the ultimate capacity (failure) of a structure. Testing for service-load levels (a) are often divided into two groups [4]:
- Diagnostic tests in the linear elastic stage to update the analytical model of a bridge so that the allowable load can be better defined.

- Proof loading tests to demonstrate that the intended loads can be carried. Higher loads are usually used than in diagnostic tests.

Recommendations for proof loading are given in some codes and stop criteria are given to prevent damage. The criteria often prescribe maximum values for concrete and steel strains, crack widths and residual deflections. Brittle failures are feared so bridges with a risk for shear failure are usually not allowed to be proof loaded.

Testing to failure (b) can be used to increase the knowledge of the real function of a type of structure and how well codes can predict the loadcarrying capacity [5]. Load testing to failure is often more expensive than diagnostic and proof 
load tests where standardized load rigs or trucks with known weight can be used.

\section{Experiences from Croatia}

On the evening of March, 30, 2009, an unexpected collapse occurred for the railway bridge Jakuševac in Zagreb when a locomotive with 26 wagons was passing over it. Due to a high level of the Sava River and many years of scouring of bed material, one of the pillars suffered a partial collapse [Figure $1 \&$ Figure 2], [6].

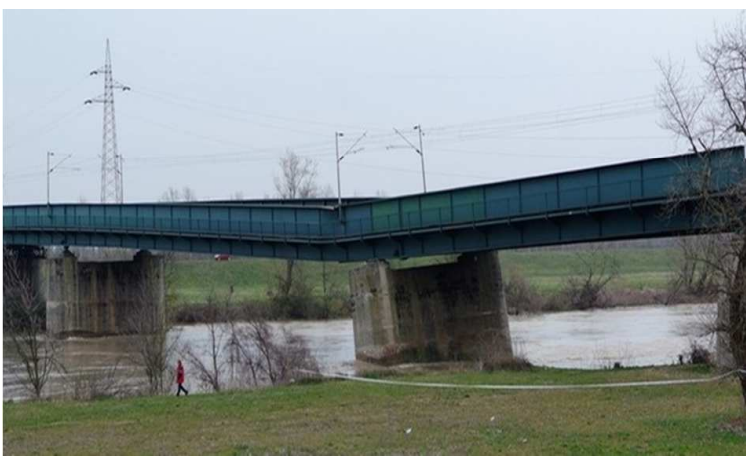

Figure 1. Partially collapsed bridge Jakuševac over the Sava River, side view [6]

The Jakuševac Bridge is a typical riveted double track bridge built in 1968. The static system consists of two main continuous I-girders (height $3,8 \mathrm{~m}$, transversal distance $9,1 \mathrm{~m}$ ) over three main spans $(34,6 m+65,9 m+34,6 m=135,1 m)$ with cross girders and bracings.

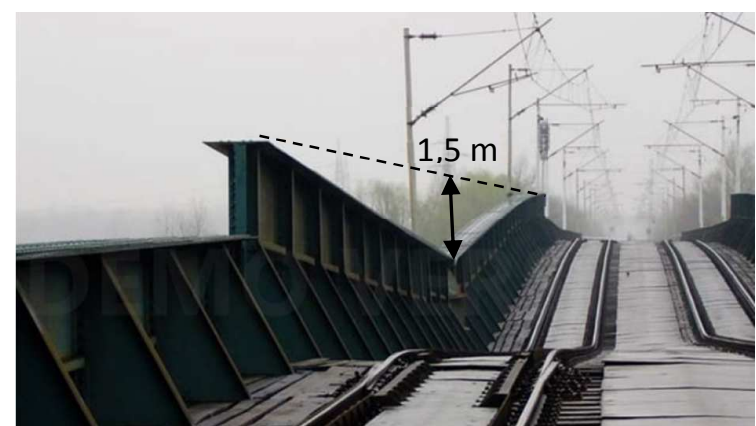

Figure 2. Plastic deformation of the bridge

Due to the lowering of the support, the bridge was subjected to excessively high compressive and tensile stresses, especially in the zones were the initial bending moment was close to zero. This region was not designed for large stresses, so a plastic zone developed [Figure 3]. Furthermore, due to self-weight of the structure and the new static system (continuous girder with a plastic hinge) one of the two main girders at an end span was lifted and no longer supported by the column S4. This further increased the bending moment on the support S5. In addition to the vertical movement, the bridge suffered a horizontal shift and serious damage of the bottom secondary members.
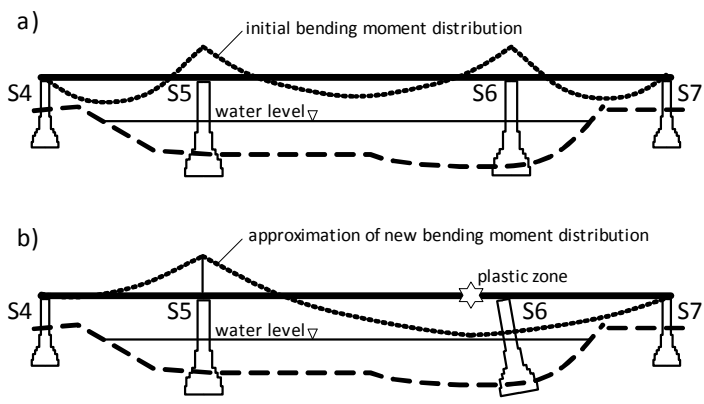

Figure 3. Resulting moment distribution a) initial and b) after lowering of the inner support

The damage required a demanding rehabilitation project $[7,8]$, which was staged in the following three steps: (a) construction of temporary working supports, (b) positioning of the bridge at its design centre line, (c) strengthening of the damaged bridge elements (main and secondary steel elements, column and foundation S6).

\subsection{Measurements during the lifting}

When the construction of the temporary supports was finished, the bridge was lifted to its design centre line [Figure 4]. During the lifting, the strains were recorded in the two weakest cross sections close to the pinned support ( 55 ) and close to the plastic zone.

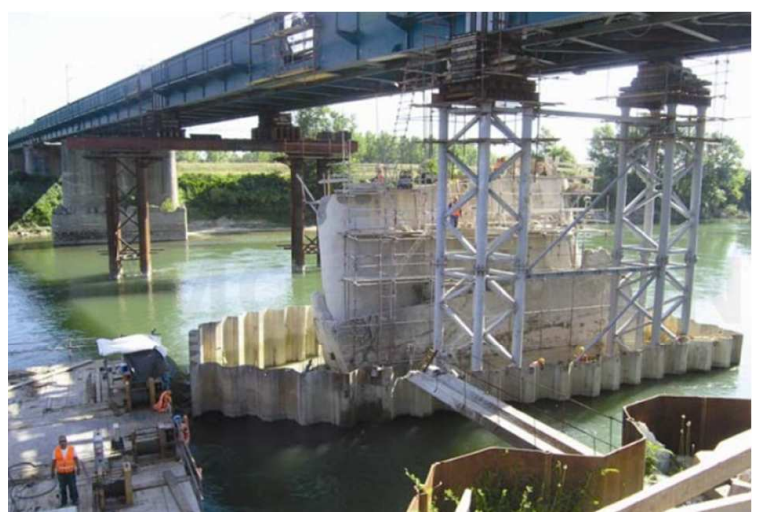

Figure 4. Lifting stage using temporary supports 


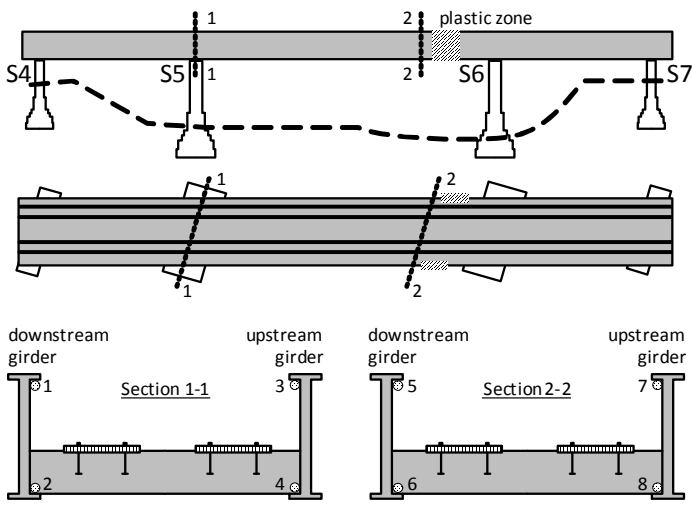

Note: measurement positions 1 to 8 are located on the main longitudinal girder

\section{Figure 5. Measuring locations for strain recording}

During each stage of the lifting, the bridge was raised 5 to $10 \mathrm{~cm}$ with hydraulic jacks. It took three days.

Based on the measured strains, stresses were calculated as a function of time [Figure 6], using Young's Modulus $E=200 \mathrm{GPa}$. Each peak in the graph presents one of the lifting stages of the structure. According to the recordings, the bridge behaved in an elastic manner during the lifting.

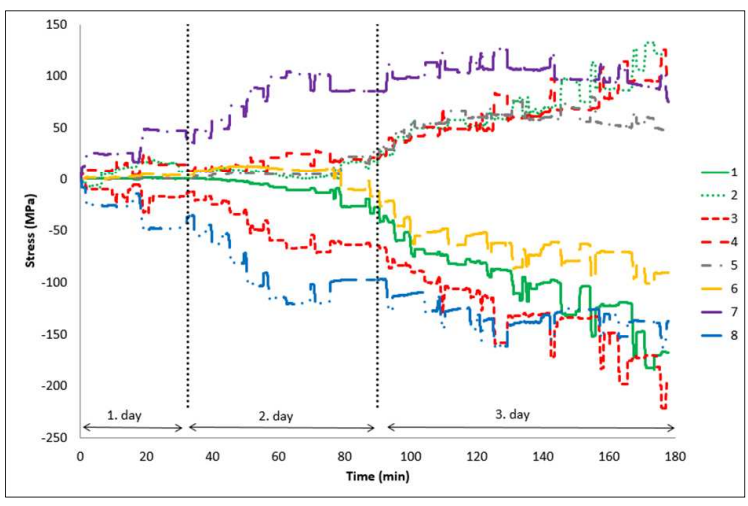

Figure 6. Stresses for lifting steps

\subsection{Diagnostic load testing}

After successful positioning of the bridge at its design centre line and after strengthening of all the damaged bridge elements, a diagnostic load test was performed. According to current legislation in Croatia (HRN U.M1.046) [9] all new and repaired railway bridges with a span greater than $10 \mathrm{~m}$, have to be subjected to a load test in order to verify their response to static and dynamic loads.
The purpose of this load test is to empirically quantify the load bearing capacity of the structure, i.e., to verify the theoretical model of the behaviour after reconstruction. The static and dynamic load tests were performed using six electric locomotives (three in each track line). Each of the four-axle locomotives had a total mass of $80 \mathrm{t}$ (axle load of $20 \mathrm{t}$ each).

\subsubsection{Static load test}

The static load test consisted of fifteen loading and unloading sequences [Table 1]. Ten loading sequences $(\mathrm{T} 1-\mathrm{T} 10)$ were applied in order to have both symmetrical and unsymmetrical loading conditions to obtain maximum load effects.

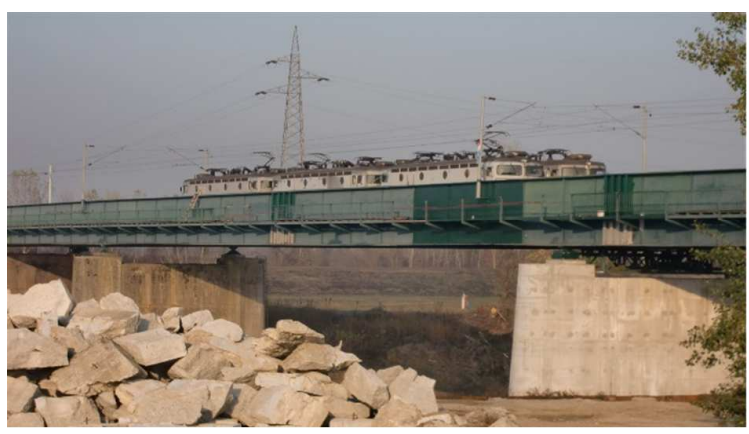

Figure 7. Maximum load effect at the middle span

The vertical displacements of the bridge were measured using geodetic methods, comprising 26 points located along the bridge [Figure 8]. A total of 22 LVDT's were installed to monitor the strains of the bridge in four cross sections. One LVDT was used to measure the horizontal displacement of the support S4 [Figure 9 \& Figure 10].

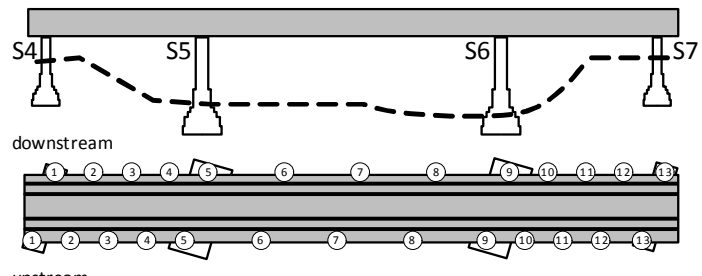

Figure 8. Points for displacement measurements

The maximum measured displacement was 54 $\mathrm{mm}$ in loading stage T7 [10] for the maximum load in the middle span. Strain recordings during the static test for configuration $\mathrm{T} 5$ and $\mathrm{T} 6$ are presented in Figure 11, [10]. 
Table 1. Loading and unloading sequences

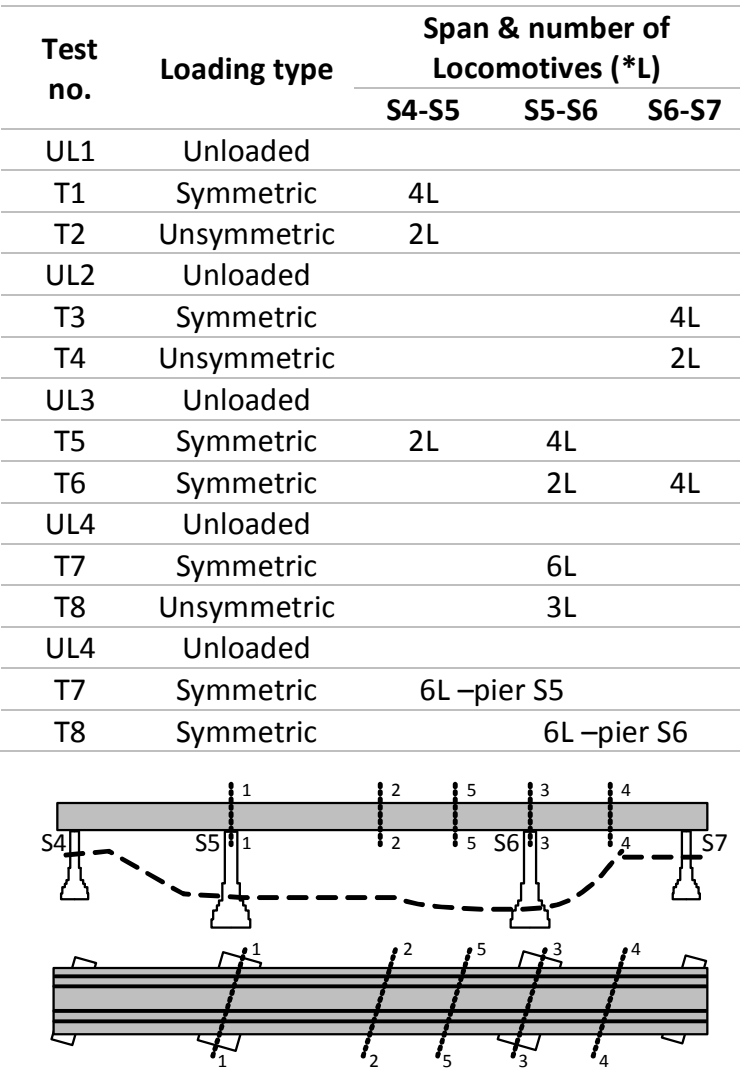

Figure 9. Sections for strain measurement

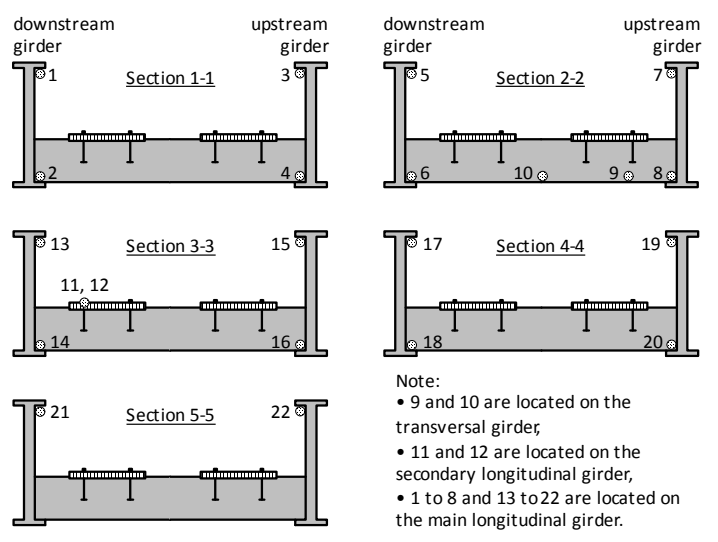

Figure 10. Points for strain measurement

\subsubsection{Dynamic load test}

In addition to information of the natural frequencies, modal shapes [Figure 12] and damping ratios of the bridge, the dynamic tests provide a picture of the variation in the dynamic amplification factor with speed [Table 2]. This test

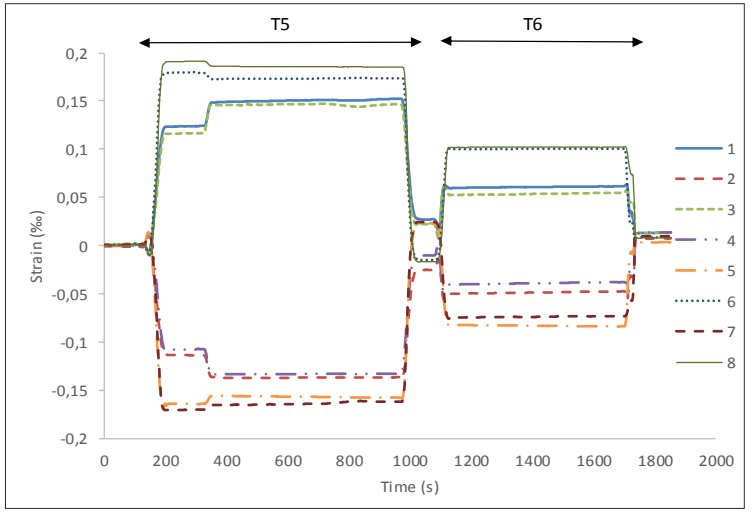

Figure 11. Recordings of strains for T5 and T6

was conducted after the static load test by using two locomotives. The dynamic parameters were captured by using accelerometers in six points of the middle span.

At the end, all results were compared with theoretical values based on a FE-model of the bridge presented in [10]. The numerical model used for the structural analysis of the bridge was updated according to the measured displacements, strains and natural frequencies.

The bridge behaved elastic both during the static test and the dynamic test.

Table 2. Dynamic amplification factor

\begin{tabular}{ccc}
\hline $\begin{array}{c}\text { Number of } \\
\text { locomotives }\end{array}$ & $\begin{array}{c}\text { Speed } \\
{[\mathrm{km} / \mathrm{h}]}\end{array}$ & $\begin{array}{c}\text { Dynamic } \\
\text { amplification factor }\end{array}$ \\
\hline \multirow{2}{*}{1} & 20 & 1,042 \\
\cline { 2 - 3 } & 40 & 1,066 \\
\hline 2 & 40 & 1,073 \\
\hline & 60 & 1,029 \\
\hline
\end{tabular}

Figure 12. Measured first mode shape $3,03 \mathrm{~Hz}$

\section{Experiences from Sweden}

Some examples are given in Table 3, [11]. 
Table 3. Examples of full-scale load testing to failure in Sweden.

\begin{tabular}{|c|c|c|c|}
\hline Type & oto & Tests and Results & Ref. \\
\hline 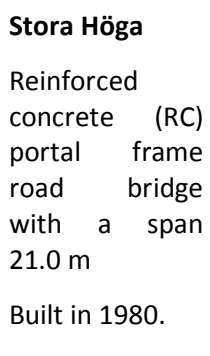 & 플 & $\begin{array}{l}\text { The bridge was strengthened with externally } \\
\text { bonded steel plates to avoid a bending failure. } \\
\text { Loads were produced by using four hydraulic } \\
\text { jacks anchored in the bedrock. } \\
\text { Brittle shear failure at the supporting wall at a } \\
\text { load of } 4.6 \mathrm{MN} \text {. The theoretically assessed } \\
\text { capacity with the Swedish code was only } 48 \% \text { of } \\
\text { the test value. }\end{array}$ & $\begin{array}{l}\text { Plos et al. } \\
\text { (1990), [12] } \\
\text { Täljsten } \\
\text { (1994), [13] } \\
\text { Plos (1995), } \\
\text { [14] } \\
\text { Bagge et al. } \\
\text { (2018), [5] }\end{array}$ \\
\hline $\begin{array}{l}\text { Lautajokk } \\
\text { RC single- } \\
\text { trough railway } \\
\text { bridge with a } \\
\text { span of } 7.0 \mathrm{~m} \text {. } \\
\text { Built in } 1967 .\end{array}$ & & $\begin{array}{l}\text { The axle loads on an iron ore railway line was to } \\
\text { be increased from } 250 \text { to } 350 \mathrm{kN} \text {. In order to } \\
\text { investigate the fatigue capacity, this bridge was } \\
\text { tested with an axle load of } 360 \mathrm{kN} \text { during } 6 \\
\text { million load cycles using hydraulic jacks. The } \\
\text { shear capacity was studied of the connection of } \\
\text { the slab to the longitudinal beams, where no } \\
\text { shear reinforcement was present. After the cyclic } \\
\text { loading, not resulting in any detectable damages, } \\
\text { the load was increased to yielding of the } \\
\text { longitudinal bending reinforcement. }\end{array}$ & $\begin{array}{l}\text { Thun et al. } \\
\text { (2000), [15] } \\
\text { Elfgren } \\
\text { (2015), [16] }\end{array}$ \\
\hline $\begin{array}{l}\text { Örnsköldsvik } \\
\text { Continuous RC } \\
\text { single-through } \\
\text { railway bridge } \\
\text { with spans of } \\
11.9 \mathrm{~m} \text { and } 12.2 \\
\mathrm{~m} \text {. } \\
\text { Built in } 1955 .\end{array}$ & & $\begin{array}{l}\text { The bridge was strengthened with near surface } \\
\text { mounted carbon fibre reinforced polymer (CFRP) } \\
\text { bars to avoid a bending failure. The loading was } \\
\text { produced by using two hydraulic jacks anchored } \\
\text { in the bedrock. } \\
\text { Brittle bond failure of CFRP followed by shear- } \\
\text { bending-torsion failure at } 11.7 \text { MN. The } \\
\text { theoretically assessed capacity with codes was } \\
65 \text { to } 78 \% \text { of the test value. }\end{array}$ & $\begin{array}{l}\text { Sustainable } \\
\text { Bridges } \\
\text { (2007), [17] } \\
\text { Puurula et } \\
\text { al. (2012 - } \\
\text { 15), [18-20] } \\
\text { Bagge et al. } \\
\text { (2018), [5] }\end{array}$ \\
\hline $\begin{array}{l}\text { Åby river } \\
\text { Steel truss } \\
\text { railway bridge } \\
\text { with a span of } \\
33 \mathrm{~m} \\
\text { Built in } 1955 .\end{array}$ & & $\begin{array}{l}\text { The bridge was placed beside the original site at } \\
\text { Áby river and loaded with two hydraulic jacks } \\
\text { anchored in the bedrock. } \\
\text { A failure initiated by fatigue was expected but } \\
\text { instead buckling occurred in the two longitudinal } \\
\text { top girders for } 11 \text { MN. The bridge was designed } \\
\text { for about } 35 \% \text { of the failure load. }\end{array}$ & $\begin{array}{l}\text { Mainline } \\
\text { (2014), [21] } \\
\text { Häggström } \\
\text { (2016), [22] } \\
\text { Häggström } \\
\text { et al. } \\
\text { (2017), [23] }\end{array}$ \\
\hline 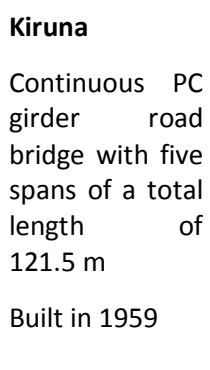 & 14 & $\begin{array}{l}\text { The bridge was monitored for } 8 \text { years to check } \\
\text { settlements due to mining. The bridge was there- } \\
\text { after loaded in the } 2 \text { nd span by hydraulic jacks } \\
\text { anchored in the bedrock. Longitudinal non- } \\
\text { prestressed reinforcement and vertical shear } \\
\text { reinforcement yielded. In the final stage, stirrups } \\
\text { ruptured and the loading plate punched through } \\
\text { the slab. The maximum load was } 13.4 \mathrm{MN} \text { and } \\
\text { the girder was designed for } 22 \% \text { of the failure } \\
\text { load. }\end{array}$ & $\begin{array}{l}\text { Bagge } \\
\text { (2017), [24] } \\
\text { Bagge et al. } \\
\text { (2018), [5] } \\
\text { Huang et al. } \\
\text { (2016), [25] } \\
\text { Nilimaa } \\
\text { (2015), [26] }\end{array}$ \\
\hline
\end{tabular}


The overall aim has been to investigate and evaluate the safe function of bridges, as exemplified in Table 3, for increased loads at the serviceability and ultimate limit states and to improve modelling, [11].

The main result of the tests at service-load levels is that many bridges have a "hidden" capacity and could carry higher loads than what is obtained applying ordinary design rules. In these tests probabilistic analysis was also identified as a viable tool for the assessment

Numerical tools as linear and non-linear finite element methods have been shown to be useful for assessment, especially combined with material testing and step-wise refinements from linear to non-linear modelling of bending, shear and anchorage [24], [28].

In numerous studies, see e.g. [5], large differences have been demonstrated between standard structural assessment methods and more detailed analyses by using non-linear FEM. The differences have probably partly arisen from redistribution of loads during testing in statically indeterminate structures, from conservative load-carrying models, increased values of material properties and built-in properties of the supports.

Strengthening with carbon fibre reinforced polymers (CFRP) has been applied successfully in different cases. For instance, the load carrying capacity was substantially increased in the Örnsköldsvik Bridge (see Table 3). Here, non-linear finite element models of the bridge were calibrated and used to simulate the structural behaviour in a good way. It was important to accurately model tension stiffening and support conditions [19], [20]. The concrete tensile strength and fracture energy were also identified as crucial parameters in numerical modelling. Often they are determined from empirical formulae from the concrete compression strength; however, more efforts should be taken to determine these properties directly from assessed existing structures.

The structural analysis and the verification of the required level of structural safety can be carried out at several levels of increasingly complex approximation.

In addition to the choice of safety concept, the level of safety is an important issue for bridge assessment and should take into account what is already known about the structure and economical, societal and environmental risks associated with it [24], [26].

\section{Discussion}

Some lessons learnt from load testing to failure are presented in [5]. About $28 \%$ of full-scale tests on 30 bridges ended with a failure mode different to that predicted. In some cases, this was related to inaccuracies in the methods for determining the load-carrying capacity but, in the majority of cases, it was caused by a lack of insight into aspects shown to be critical, particularly associated with the shear and punching capacities and the boundary conditions. Consequently, there is a need of further studies in order to provide reliable codes and guidelines on how to accurately assess the capacity of bridges.

Scouring of bed material can be devastating to the function of a bridge. Improved monitoring and numerical methods may in the future be used to determine hidden deterioration [25].

An idea is also to create digital twin bridges which start their life (in silico) during the planning phase of a bridge [24]. The models may be integrated with monitoring of the in situ bridge to enable model updating and for later assessment of the quality and load-bearing capacity of the bridge during its life time.

\section{Conclusions}

This paper presents the experiences from a range of tested bridges in Croatia and Sweden. Most of the bridges had more capacity than the original design calculations indicated, and in several cases, a diagnostic load test was a cost-effective way to avoid strengthening or renewal of the bridge. Tests to failure may show differences, e.g. in load distribution, superstructures composite behaviour or support conditions, which often results in extra "hidden" capacity to the bridge. In a few tested 
bridges, the result was the contrary. The tests revealed damages in the bridge superstructure which made the distribution even worse than calculated and the capacity of the bridge weaker.

The collapsed bridge in Croatia learned us in an expensive manner how not to manage bridges. This bridge was an example of lack of inspection and maintenance during ages. On the other hand, the well planned monitoring during construction and load testing was a complete success and a huge amount of interesting data was collected. This data is used by the authors to understand the static and dynamic behaviour of this structure as well as to produce an initial database of the undamaged repaired structure that can be used for future condition assessment of the bridge.

Load tests are a relatively easy way to get precise information about the behaviour of a bridge and also to provide useful information about different bridge types and their typical behaviour. Tests need to be designed carefully to achieve useful results and the results need be analysed and published in order to get a full insight of its implications.

Additional work is needed regarding recommendations for load testing, proof load levels, test set up and calibration of numerical models. Above all, more tests to failure of different bridge types are suggested to give a better base for reliable assessment of existing bridges in order to improve quality control, a cost efficient bridge management and a sustainable usage of the existing bridge stock.

\section{Acknowledgements}

The support from Erasmus+ (mobility grant for the first author); Trafikverket, Sweden; EU FP 6 (Sustainable Bridges, [17]); EU FP 7 (Mainline, [21]); and many companies, institutions and colleagues are acknowledged with thanks.

\section{References}

[1] Bolle, Guido; Schacht, Gregor; Marx, Steffen. 2010. Geschichtliche Entwicklung und aktuelle Praxis der Probebelastung. (Loading tests of existing structures - history and present practise. In German). Bautechnik, 87(11\&12), 700-707 \& 784-789.

[2] COST TU 1406 WG1. 2016. Performance Indicators for Roadway Bridges of Cost Action TU1406, 40pp, http://www.tu1406.eu/

[3] COST 1406 WG2. 2017. Performance Goals for Roadway Bridges of Cost Action TU1406, 82 pp, http://www.tu1406.eu/

[4] Lantsoght, Eva O.L.; van der Veen, Cor; de Boer, Ane; Hordijk, Dick A. 2017. State-ofthe-art on load testing of concrete bridges. Engineering Structures, 150, Nov 2017, 231 241.

[5] Bagge, Niklas; Popescu, C and Elfgren, L. 2018. Failure tests on concrete bridges: Have we learnt the lesson? Structure and Infrastructure Engineering, 14(3) 292-319.

[6] Nadilo, Branko. 2011. Reconstruction of railway bridge Sava-Jakuševac (in Croatian). Journal of the Croatian Association of Civil Engineers (GRADEVINAR), 63/7, 705-709.

[7] Mujkanović, Nijaz; Vlašić, Anđelko; Šavor, Zlatko. 2012. Reconstruction of railway bridge Sava-Jakuševac. In "Construction of Infrastructure" (in Croatian) ed. by Lakušić, Stjepan. University of Zagreb, Civil Engineering, Zavod za prometnice, 85-117.

[8] Mujkanović, N; Vlašić, A. \& Oršanić, Filip. 2012. Rehabilitation of railway bridge Sava Jakuševac. Durability of Concr. Struc. - Proc. 8th Central European Congr. on Concrete Engineering, ed. by Radić, J. \& Kušter, M. Zagreb: Secon CSSE, 2012, 175-182

[9] Rak, Mladenko; Duvnjak, Ivan; Frančić, Marina. 2013. Diagnostic load test of railway bridge Sava-Jakuševac (in Croatian), Journal of Croatian Railway Infrastructure (Željeznice 21), 2/2013, 7-14.

[10] Domagoj, Damjanović; Rak, M.; Duvnjak, I.; Bartolac, Marko; Frančić, Marina. 2011. Report of diagnostic load test of railway bridge Sava-Jakuševac (in Croatian), UNIZG, 2011, 7-14.

[11] Elfgren, L; Täljsten, B; Blanksvärd, T; Sas, G; Nilimaa, J; Bagge, N; Tu, Y; Puurula, A; 
Häggström, J; Paulsson, B. 2018. Load testing used for quality control of bridges. COST TU 1406, Wroclaw, 1-2 March, 6 pp, http://www.tu1406.eu/

[12] Plos, Mario, Gylltoft, Kent, \& Cederwall, Krister. 1990. Full scale shear tests on modern highway concrete bridges. Nordic Concrete Research, 9, 134-144.

[13] Täljsten, Björn. 1994. Plate bonding strengthening of existing concrete structures with epoxy bonded plates of steel or fibre rf plastics (PhD). Luleå Univ. of Tech., 205 pp. http://ltu.diva-portal.org/

[14] Plos, Mario. 1995. Application of fracture mechanics to concrete bridges. Finite element analyses and experiments (PhD). Chalmers Univ. of Tech., Gothenburg.

[15] Thun, Håkan; Ohlsson, Ulf; Elfgren, L. 2000. Fatigue Capacity of Small Railway Concrete Bridges: Prevision of the Results of Swedish Full-scale Tests. ERRI D216, Luleå Univ. of Tech., 99 pp. http://ltu.diva-portal.org/

[16] Elfgren, Lennart. 2015. Fatigue Capacity of Concrete Structures: Assessment of Railway Bridges. Res. Rep., Struct. Eng., Luleå Univ. of Tech., 103 pp. http://ltu.diva-portal.org/

[17] Sustainable Bridges. 2007. Assessment for Future Traffic Demands and Longer Lives. A European FP 6 Integr. Res. Proj. 2003-2007. Four guidelines $\& 35$ backgr. docs. available at www.sustainablebridges.net

[18] Puurula, Arto. 2012._Load-carrying Capacity of a Strengthened Reinforced Concrete Bridge: Non-linear..., PhD, Luleå Univ. of Tech., ISBN 978-91-7439-433-7, 332 p. http://ltu.diva-portal.org/

[19] Puurula, Arto, Enochsson, O, Sas, G, Blanksvärd, T, Ohlsson, U, Bernspång, L, Elfgren, L. 2014. Loading to failure and 3D nonlinear FE modelling of a strengthened RC bridge. Structure \& Infrastructure Engineering, 10(12), 1606-1619.

[20] Puurula, Arto, Enochsson, O, Sas, G, Blanksvärd, $T$, Ohlsson, $U$, Bernspång, $L$, Täljsten, B, Carolin, A, Paulsson, B, Elfgren, L. 2015. Assessment of the Strengthening of an RC Railway Bridge with CFRP Utilizing a Full-Scale Failure Test and Finite-Element Analysis, J. Struct. Engineering, ASCE, 2015 141, D4014008, $11 \mathrm{p}$.

[21] MAINLINE 2014. MAINtenance, renewaL and Improvement of rail transport INfrastructure to reduce Economic and environmental impacts. A Eur. FP7 Res. Proj. 2011-2014. Twenty reports are available at http://www.mainline-project.eu/

[22] Häggström, Jens. 2016. Evaluation of the Load Carrying Capacity of a Steel Truss Railway Bridge: Testing, Theory and Evaluation. Lic. Thesis, Luleå Univ. of Tech., 142 pp. http://ltu.diva-portal.org/

[23] Häggström, Jens; Blanksvärd, Thomas; Täljsten, Björn. 2017. Bridge over Åby River - Evaluation of full scale testing. Res. Rep, Div. of Struct. Eng., Luleå Univ. of Tech., 180 pp. http://ltu.diva-portal.org/

[24] Bagge, Niklas. 2017. Structural Assessment Procedures for Existing Concrete Bridges. Experiences... of the Kiruna Bridge. PhD Lulea Univ. of Tech., ISBN 978-91-7583-8793, 310 pp. http://ltu.diva-portal.org/

[25] Huang, Zheng; Grip, N; Sabourova, N Bagge, N; Tu, Y; and Elfgren, L. 2016. Modelling of damage and its use in assessment of a prestressed bridge. $19^{\text {th }}$ Congr. of IABSE Stockholm, pp 2093-2108. http://ltu.diva-portal.org/

[26] Paulsson, Björn; Bell, B; Schewe, B; Jensen, J S; Carolin, A; Elfgren, L. 2016. Results and Experiences from European Research Projects on Railway Bridges. $19^{\text {th }}$ IABSE Congress Stockholm, 2570-2578. ISBN 9782-85748-144-4. http://Itu.diva-portal.org/

[27] Nilimaa, Jonny. 2015. Concrete bridges: Improved load capacity. PhD, Luleå Univ. of Tech., Sweden, 180 pp., http:///tu.divaportal.org/

[28] Hendriks, M.A.N.; de Boer, A; Belletti, B. 2017. Guidelines for Nonlinear FEA of Concrete Structures, Rijkswaterstaat Centre for Infrastructure, Report RTD:1016-1:2017, The Netherlands, $69 \mathrm{pp}$. 